\title{
Effect of Listing Age on Corporate Financial Leverage of Oil and Gas Firms in Nigeria
}

\section{Inyiama Oliver Ikechukwu, Ubesie Madubuko Cyril}

Department of Accountancy, Faculty of Management Sciences, Enugu State University of Science and Technology, Enugu, Nigeria

Email address:

ubesiemadubuko@yahoo.com (Ubesie M. C.)

\section{To cite this article:}

Inyiama Oliver Ikechukwu, Ubesie Madubuko Cyril. Effect of Listing Age on Corporate Financial Leverage of Oil and Gas Firms in Nigeria. International Journal of Economics, Finance and Management Sciences. Vol. 5, No. 2, 2017, pp. 92-97. doi: 10.11648/j.ijefm.20170502.12

Received: August 17, 2016; Accepted: January 4, 2017; Published: January 26, 2017

\begin{abstract}
Examination of the effect of listing age on corporate financial leverage of oil and gas firms in Nigeria is the main objective of this study. The study also considers, for sake of robustness, the trend of movement of the variables, the relationships among the variables, as well as the causality of a variable by the other. This made the study a meta-analysis of the time series data. Simple regression was applied to estimate the effect of listing age on financial leverage of the selected firms. Correlation and Granger Causality Tests were applied to ascertain the relationships and causalities among the model variables. The outcome of the analysis is that firm's Listing Age has a significant but negative effect on Financial Leverage, which implies that, as an oil firm advances in age, the firms' need for external financing will tend to reduce. Causality test reveals that at a lagged period of one year, there is no causality running from financial leverage to firm age and vice versa. This implies that financial leverage is not caused by listing age of the oil and gas firm or otherwise. When the relationship between firm age and financial leverage was tested, the test reveals that financial leverage has an insignificant negative relationship with firm age in Nigeria Oil and Gas firms. The sustainability of theses outcomes over a long period of time was also tested using the Johansen Cointegration Test which indicates cointegrating equations which implies that short run effects and relationships are very sustainable, all things remaining the same. Therefore, firms are encouraged to borrow less as they advance in age. In conclusion, therefore, at maturity stage of the firm, external borrowing should be discouraged in preference to other sources of investible funds.
\end{abstract}

Keywords: Leverage, Oil, Life Cycle, Gas, Age, Regression, Cointegration

\section{Introduction}

Debt gives firms more financial agility in taking up investment opportunities because, in general, debt can be raised more quickly than either equity finance or the accumulation of earnings as Debt might also enable firms to increase their after tax earnings by exploiting available tax shields (Harrison and Widjaja, 2013). However, the firm's choice of an optimal capital structure, remains one of the large unresolved issues in the financial economics literature (Myers, 2001). The trade-off model, which argues that firms choose the optimal level of debt by trading off the benefits of debt against its costs and the theory provides that there is an optimal level of debt which is attained when the marginal benefit equals the marginal cost of an additional unit of debt (Antão and Bonfim, 2012).

Pecking order theory by Myers (2001) predicts that companies should use stock issuances to cover financing deficits only as a last resort, after cheaper, less information sensitive alternatives (like internal cash, bank debt, or public debt) have been exhausted. Firm growth, capital intensity, advertisement intensity, age of firm, business cycle trends among others were suggested as factors capable of determining profitability and by extension, level of financial leverage. Robb and Robinson (2009) found that gains from financial leverage are quite significant in relation to financial performance and the use of debt enhances the firm market value. Ezeoha and Botha (2011) states that during start-up and maturity stages, a firm's access to debt markets is significantly influenced by investments in assets that are acceptable to external creditors as collateral. The researchers noted that among the most dominant corporate financing challenges in most developing economies is the persistent scarcity of loan capital. 
National Bureau of Statistics (2014) states that in the first quarter of 2014, Nigeria's Nominal Gross Domestic Product, GDP (at basic prices) was estimated at N20,169,778.04 million, or $15,438,679.50$ million in real terms. It stated that the corresponding quarter of 2013, nominal GDP was estimated N18,295, 631.91 or N14,535,420.95 million in real terms and as a result, the growth rate of real GDP was recorded at $6.21 \%$ in Q1 2014, higher than $4.45 \%$ recorded in the corresponding quarter of 2013 , but lower than $6.77 \%$ recorded in the fourth quarter of 2013. Furthermore, the average daily crude oil production in the opening quarter of 2014 stood at $2.26 \mathrm{mbpd}$, down from the $2.29 \mathrm{mbpd}$ recorded in the corresponding quarter of 2013. In addition, it recorded that in Q1 2014, oil GDP was valued at N2,612,066.21 million in nominal terms, compared to N2,756,313.26 recorded in the corresponding quarter of 2013 and Real growth in the Oil sector was recorded at $-6.60 \%$ in Q1 2014, indicating better performance compared to $-11.40 \%$ growth recorded in the corresponding 2013 quarter and the $-9.36 \%$ growth recorded in the fourth quarter of 2013. The oil sector also grew by 1.18 per cent in the fourth quarter of 2014 , 10.54 percent higher than the decline of 9.36 per cent recorded in the fourth quarter of 2013 (NBS, 2014). The sector is a key sector in Nigeria because of its contribution to National GDP.

However, Ali (2013) opines that to attain optimal capital structure remains a puzzle to every manager and board of directors and failure to put considerations on capital structure might lead to low profitability, bankruptcy, failure to invest in high returns project and ultimately decrease in the value of the firm. The key responsibility of determining the optimal mix of debt and equity that will ensure maximization of shareholders wealth falls under the financial managers (Maina and Kondongo, 2013). Ahmad and Javid (2009) have expressed four steps to describe the age cycle of the company as (1) the introduction stage, (2) the growth stage, (3) the maturity stage, and (4) the decline stage.

The analytical procedure will involve the examination of the effect of firm age on the firm's financial leverage needs in the oil and gas industry of Nigeria. It will also assess the causality and relationship between company age and the extent of their financial leverage. The remaining part of the paper is arranged into four distinct sections as follows: section 2.0 will review existing literature in the area of study, section 3 will state the methodology to be adopted for data collection and analysis, section 4 will discuss the findings/outcome of the data analysis, while section 5 concludes.

\section{Review of Related Literature}

The theoretical framework upon which the study is underpinned is the Lifecycle Theory proposed by Mueller (1972) and the trade-off theory of capital structure proposed by Kraus and Litzenberger (1973). Trade-off theory of capital structure refers to the idea that a company chooses how much debt finance and how much equity finance to use by balancing the costs and benefits. Kraus and Litzenberger
(1973) considered a balance between the dead-weight costs of bankruptcy and the tax saving benefits of debt. The tradeoff theory argues that the correlation between profitability and leverage ratio is positive which implies that the higher the profit, the higher the leverage ratio. Indeed, consideration tax system and bankruptcy costs suggest the existence of an optimal ratio of debt (target ratio). The current theory is known as the theory of compromise the Static Trade-off Theory (STT). The relevance of different factors used by the STT to explain the financial behavior of companies has been confirmed by several empirical studies (Titman and Wessels, 1988) and Rajin and Zingales (1995), as cited in Ghazouani (2013).

Mueller (1972) focused on the agency problem within a firm, namely the question of whether the managers of a firm maximize shareholder value, or pursue growth for its own sake and "over invest" in assets contrary to shareholder interests. Life Cycle theory contends that dividend policy is driven by the tradeoff between distribution and retention of corporate earnings and that this tradeoff depends on firm maturity stage as it is believed that young firms rely more on new equity (or contributed equity) for early growth while mature firms rely more on self-financing and are more able to pay dividends because of ample accumulative profits (Ekwe and Inyiama, 2014). Mueller (1972) believes that at mature stage, a shareholder value-maximizing firm would begin distributing its earnings to its shareholders as the firm might have reached a point where it lacks profitable investment opportunities for the cash generated from its existing operations.

Tamimi and Takhtaei (2014) examined the effect of financial leverage on the age of the company. In this case, two hypotheses were formulated. In the first hypothesis, the effects of the age of the company and also in second hypothesis the effects of the financial leverage on the policies of profit distribution of the company were investigated, using sample manufacturing companies accepted in Tehran Stock Exchange (TSE) over the period from 2005 to 2011 . To investigate the linear or non-linear relationship between company age and dividends, the square and the cube of the company age in empirical model of the research were used. The results indicate a positive and significant relationship between company age and dividend ratio, but a negative and significant association between financial leverage and dividend.

Ezeoha and Botha (2011) applies the Blundell and Bond system generalized method of moments (GMM) two-step estimator to examine the impact of age and collateral value on debt financing, using a panel of 177 nonfinancial companies listed on the Johannesburg Stock Exchange over the period 1999 to 2009. The results show that South African firms have target leverage ratios and adjust their capital structures from time to time to achieve their respective targets, that the relationship between firm age and debt financing is non-monotonic, and that firms with higher collateral value are likely to face fewer constraints on borrowing and therefore have greater access to medium-term and long-term debts. Robustness tests also reveal that during start-up and maturity stages, a firm's access to debt markets 
is significantly influenced by investments in assets that are acceptable to external creditors as collateral. These findings suggest that debt financing policies could be more critical for firms in the start-up and maturity stages.

An investigation of the existence of a pecking order in new technology-based firms (NTBFs) financing was carried out by Cassia and Minola (2011). The study provides evidence on factors determining what source of capital NTBFs try to access. The authors paid particular attention to aspects of human capital such as age, education and experience and focus on potential singularities exhibited by young novice entrepreneurs and potential constraints that they experience. These entrepreneurs were found not to be financially constrained. The findings also contribute to the academic debate on the existence of a reversed pecking order for NTBFs. Results confirm traditional pecking order patterns and show that NTBFs do rely heavily on external debt, contradicting the most common theoretical predictions. However data also suggest that (as a new perspective) some light can be shed on the hierarchy between debt and equity as financial source preferred by NTBF when it is investigated from a longitudinal rather than a cross-sectional perspective.

Sherif and Elsayed (2013) opines that the capital structure of a firm is extremely important to its success and continuation as a going concern and can be seen as a key source of a firm's value. The paper identified the driving forces that influence capital structure of Egyptian insurance companies, by using a number of econometric techniques and hand-collected data over the period from 2006 to 2011. It demonstrates that firm size, tangibility of assets, profitability and firm age factors are positively related to the total leverage (LEV). The study also provides evidence that growth opportunities, liquidity and non-debt tax shield appear to be the significant factors that adversely influence the total leverage (LEV) and capital structure. The findings of Sherif and Elsayed (2013) were not in tandem with that of Bevan and Danbolt (2002) which show a strong and inverse relationship between debt ratio and profitability.

\section{Methodology}

The study is an ex post facto research (after the fact research) which provides a systematic and empirical solution to research problems, by using data which are already in existence. The study was carried out in Nigeria Oil and Gas Sector. Data on firm characteristics and capital structure variables were extracted from the annual report and accounts of the firms (Oando Plc, Mobil Plc, Conoil Plc and Total Plc) between 2000 and 2014.

The simple regression (prediction) model is statistically written as,

$$
\text { FINLEV }_{\mathrm{t}, \mathrm{i}}=\beta_{\mathrm{o}}+\beta_{1} \text { FIRMAGE }_{\mathrm{t}}+\mathrm{e}_{\mathrm{t}}
$$

Where,

FINLEV $=$ Financial Leverage

FIRMAGE $=$ Firm Age

$\beta_{\mathrm{o}}=$ coefficient (constant) to be estimated $\beta_{1}=$ parameter of the independent variable to be estimated

$\mathrm{t}=$ current period

$\mathrm{e}=$ stochastic disturbance (error) term

Granger-Causality test is conducted in the context of linear regression models and specified in bivariate linear autoregressive model of two variables $\mathrm{X}_{1}$ and $\mathrm{X}_{2}$ based on lagged values as applied by Pasquale (2006):

$$
\begin{aligned}
& X_{1}(\mathrm{t})=\sum_{j=1}^{p} A_{11 j} X_{1}(t-j)+\sum_{j=1}^{p} A_{12 j} X_{2}(t-j)+E_{1}(t) \\
& X_{2}(\mathrm{t})=\sum_{j=1}^{p} A_{21 j} X_{1}(t-j)+\sum_{j=1}^{p} A_{22 j} X_{2}(t-j)+E_{2}(t)
\end{aligned}
$$

Where;

$p$ is the maximum number of lagged observations included in the equation, the matrix $A$ contains the coefficients of the equation (i.e., the contributions of each lagged observation to the predicted values of $\mathrm{X}_{1}(t)$ and $\mathrm{X}_{2}(t)$,

$\mathrm{X}_{1}$ is the FINLEV which is constant while $\mathrm{X}_{2}$ is the FIRMAGE values, and

$E 1$ and $E 2$ are residuals (prediction errors) for each time series data.

\section{Discussion of Findings}
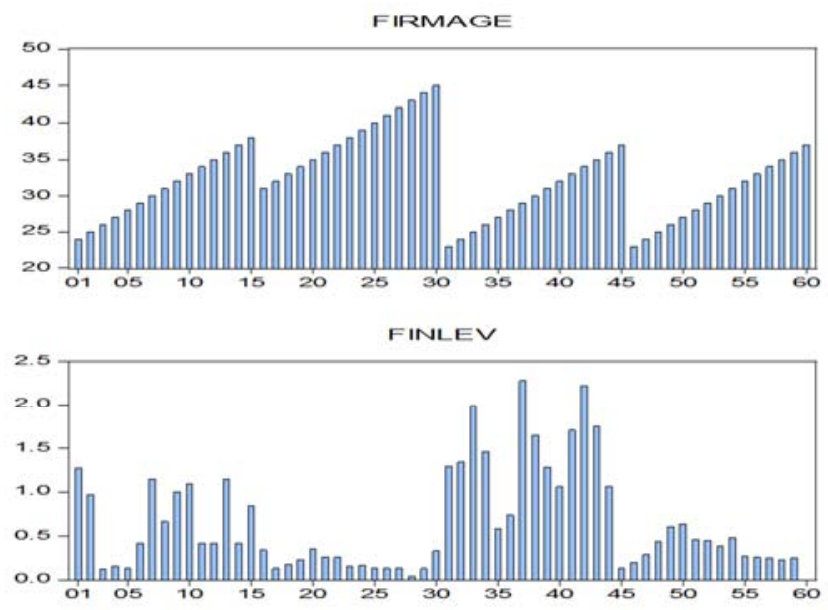

Source: Author's EView 8.0 Output.

Figure 1. Graphical Representation of the Variables after differencing at I(1).

Figure 1 reveals the pattern of movement of the focal and explanatory variables from 2000 to 2014 accounting year of the firms. A closer observation of the line graphs above reveal that firm age naturally and in line with expectations is having a smooth rise as it moves through the trajectory of its' life cycle. Firm age increases each year by a unit for all the four companies under study.

On the other hand, the graph depicting the movement of financial leverage along the firms' life cycle reveals that firms' borrowing over the period 2000 to 2018 fluctuates. Most of the firms had low loan profile at the beginning of 2000, had a bigger exposure to external borrowings around 2008 and reduced the borrowing drastically towards 2014 . This trend could be associated with the excruciating economic melt-down/financial crisis experienced around 2008 in Nigeria and beyond. 
Table 1. Descriptive Statistics of the Variables.

\begin{tabular}{lll}
\hline STATISTICS & FIRMAGE & FINLEV \\
\hline Mean & 32.16949 & 0.661525 \\
Median & 32.00000 & 0.420000 \\
Maximum & 45.00000 & 2.280000 \\
Minimum & 23.00000 & 0.040000 \\
Std. Dev. & 5.521596 & 0.581994 \\
Skewness & 0.289293 & 1.150772 \\
Kurtosis & 2.455066 & 3.383448 \\
Jarque-Bera & 1.552963 & 13.38349 \\
Probability & 0.460022 & 0.001241 \\
Sum & 1898.000 & 39.03000 \\
Sum Sq. Dev. & 1768.305 & 19.64556 \\
Observations & 59 & 59 \\
\hline
\end{tabular}

Source: Author's EView 8.0 Output.

Table 1, describes the statistics of the focal and explanatory variables of the study. The coefficient of skewness of FIRMAGE ( 0.289293) is lower than one and this portends a normal frequency distribution. That of FINLEV is approximately 1 (1.150772) signifying a normal frequency distribution also. Jarque-Bera statistic shows that FIRMAGE and FINLEV have p- values of 1.552963 and 13.38349 respectively. Both Kurtosis and Jarque-Bera statistic confirm that the time series data were normally distributed for FIRMAGE and FINLEV. The standard deviation was significantly volatile for FIRMAGE as it stands at 5.521596 .

Table 2. Regression Analysis.

\begin{tabular}{|c|c|c|c|c|}
\hline \multicolumn{5}{|c|}{ Dependent Variable: FINLEV } \\
\hline \multicolumn{5}{|c|}{ Method: Least Squares } \\
\hline \multicolumn{5}{|c|}{ Date: $07 / 22 / 16$ Time: $22: 29$} \\
\hline \multicolumn{5}{|c|}{ Sample (adjusted): 00010059} \\
\hline \multicolumn{5}{|c|}{ Included observations: 59 after adjustments } \\
\hline Variable & Coefficient & Std. Error & $\mathrm{t}$-Statistic & Prob. \\
\hline FIRMAGE & -0.034573 & 0.013189 & -2.621413 & 0.0112 \\
\hline $\mathrm{C}$ & 1.773715 & 0.430371 & 4.121365 & 0.0001 \\
\hline R-squared & 0.107587 & \multicolumn{2}{|c|}{ Mean dependent var } & 0.661525 \\
\hline Adjusted R-squared & 0.091931 & \multicolumn{2}{|c|}{ S. D. dependent var } & 0.581994 \\
\hline S. E. of regression & 0.554597 & \multicolumn{2}{|c|}{ Akaike info criterion } & 1.692161 \\
\hline Sum squared resid & 17.53195 & \multicolumn{2}{|c|}{ Schwarz criterion } & 1.762586 \\
\hline Log likelihood & -47.91875 & \multicolumn{2}{|c|}{ Hannan-Quinn criter. } & 1.719652 \\
\hline F-statistic & 6.871807 & \multicolumn{2}{|c|}{ Durbin-Watson stat } & 0.636460 \\
\hline Prob(F-statistic) & 0.011208 & & & \\
\hline
\end{tabular}

Source: Researcher's EView 8.0 Computation

Table 2 reveals that Firm Age has a significant but negative effect on Financial Leverage. This implies that as an oil firm advances in age, the firms' need for external financing will tend to reduce. This is in line with the researcher's a priori expectation. The Oil and Gas firms need a lot of funding for the acquisition of the heavy and expensive machines deployed for geological, geophysical and actual drilling operations. However, to reduce the cost of funding and borrowing, the Oil and Gas firms conserve a greater percentage of their profit, as retained earnings, which they plough back into business. Consequently, as the firm increases in age, the accumulated revenue reserves increase to such an extent that it solves the firms' investible cash requirements. If the oil firms must source external funding, they prefer to do that through the stock market; which is still cheaper than cost of bank borrowing.

Table 3. Pairwise Granger Causality Tests.

\begin{tabular}{llll}
\hline Date: 07/22/16 Time: 22:38 & & & \\
Sample: 0001 0060 & & & \\
Lags: 1 & Obs & F-Statistic & Prob. \\
Null Hypothesis: & 58 & 0.29909 & 0.5867 \\
FIRMAGE does not Granger Cause FINLEV & 58 & 0.00015 & 0.9903 \\
\hline
\end{tabular}

Source: Researcher's EView 8.0 Computation

Table 3 reveals that at Lag 1, there is no causality running from financial leverage to firm age and vice versa. This is evident from the fact that none of the p-values is less than 0.05 . The implication of the outcome is that firm age does not granger cause financial leverage and vice versa.

Table 4. Correlation Analysis Result.

\begin{tabular}{lll}
\hline & FINLEV & FIRMAGE \\
\hline FINLEV & 1.000000 & -0.328005 \\
FIRMAGE & -0.328005 & 1.000000 \\
\hline
\end{tabular}

Source: Researcher's EView 8.0 Computation

Table 4 explains that financial leverage has an insignificant negative relationship with firm age in Nigeria Oil and Gas industry. The relationship is quite insignificant because the strength of the relationship is just about 33\%. This is also in line with the researchers expectations. This is because, it is logical to assume that as company increases in age, its' asset size will also be on the increase. At the maturity stage, in line with the life cycle theory, the company would have taken up almost its' investment opportunities to such an extent that it increases the dividend paid to shareholders signifying that the company no longer requires huge retentions. At this stage also, there is not much need for external borrowing because the earnings retained on a yearly basis seems to be adequate for the few investment opportunities they may still want to try their hands on.

Table 5A. Johansen Cointegration Result.

Date: 07/22/16 Time: 22:36

Sample (adjusted): 00030059

Included observations: 57 after adjustments

Trend assumption: Linear deterministic trend

Series: FINLEV FIRMAGE

Lags interval (in first differences): 1 to 1

Unrestricted Cointegration Rank Test (Trace)

\begin{tabular}{lllll} 
Hypothesized & & Trace & 0.05 & \\
No. of CE(s) & Eigenvalue & Statistic & Critical Value & Prob.** \\
None $*$ & 0.182182 & 19.20267 & 15.49471 & 0.0132 \\
At most $1 *$ & 0.126960 & 7.739089 & 3.841466 & 0.0054 \\
\hline
\end{tabular}

Trace test indicates 2 cointegrating eqn(s) at the 0.05 level

* denotes rejection of the hypothesis at the 0.05 level

**MacKinnon-Haug-Michelis (1999) p-values

Source: Researcher's EView 8.0 Computation 
Table 5B. Johansen Cointegration Result.

\begin{tabular}{lllll}
\hline \multicolumn{4}{l}{ Unrestricted Cointegration Rank Test (Maximum Eigenvalue) } \\
\hline Hypothesized & & Max-Eigen & 0.05 \\
No. of CE(s) & Eigenvalue & Statistic & Critical Value & Prob.** \\
None & 0.182182 & 11.46358 & 14.26460 & 0.1325 \\
At most 1* & 0.126960 & 7.739089 & 3.841466 & 0.0054 \\
\hline
\end{tabular}

Max-eigenvalue test indicates no cointegration at the 0.05 level

* denotes rejection of the hypothesis at the 0.05 level

**MacKinnon-Haug-Michelis (1999) p-values

Source: Researcher's EView 8.0 Computation

Table 5 indicates 2 (two) cointegrating equations under the Trace Test and 1 (one) cointegrating equation under the Maxeigenvalue test. This situation denotes the rejection of the hypothesis that firm age has no significant effect on financial leverage of firms in Nigeria Oil and Gas firms at the 0.05 level. Whenever there is a cointegation of this sort, the implication is that the relationship which presently exist among the variables, or the effect of the independent variable (firm age) on the dependent variable (financial leverage), could be sustained both in the short and long term.

\section{Summary}

The main purpose of this research is to examine the effect of firm age on the firm's financial leverage, which is an alternative source of financing, in the oil and gas industry of Nigeria. The study also focused on assessment of the causality and relationship between company age and its' level of borrowing to provide a leverage to equity financing. The study was underpinned by two theoretical frameworks, namely; the Trade- Off Theory (Kraus and Litzenberger, 1973) and the Life Cycle Theory (Mueller, 1972).

The study is an ex post facto research (after the fact research) which provides a systematic and empirical solution to research problems, by using data which are already in existence. The analysis of the time series data reveals that Firm Age has a significant but negative effect on Financial Leverage, which implies that as an oil firm advances in age, the firms' need for external financing will tend to reduce. Causality test reveals that at Lag 1 , there is no causality running from financial leverage to firm age and vice versa. This implies that financial leverage is not caused by the age of the oil and gas firm or otherwise. When the relationship between firm age and financial leverage was tested, it was found that financial leverage has an insignificant negative relationship with firm age in Nigeria Oil and Gas firms.

The sustainability of theses outcomes over a long period of time was also tested using the Johansen Cointegration Test. The test indicates 2 (two) cointegrating equations under the Trace Test and 1 (one) cointegrating equation under the Maxeigenvalue test which implies that short run effects and relationships are very sustainable, all things remaining the same. The findings of this research are in line with the expectations of the researcher and in accordance with some existing literature in relevant area of study. The findings are linked to the theories underpinning the present study.

Therefore, firms are encouraged to borrow less as they advance in age. This is because, as firms advance in age, they are exposed to other sources of fund that are near cost free; a good example is accumulated retained earnings. Earnings could be accumulated for investment as an alternative to external borrowing when companies approach maturity. If the reserves are inadequate at a certain advanced age of the firm for investment, the firm can make a right issue to existing shareholders or issue part of the unissued authorized share capital to the public for subscription. In conclusion, therefore, at maturity stage of the firm, external borrowing should be discouraged in preference to other sources of investible funds.

\section{References}

[1] Ahmed, H., \& Javid, A. Y. (2009). Determinants of Dividend Policy in Pakistan, International Research Journal of Finance and Economics, Issue 29, pp. 110-125.

[2] Ali, K. A (2013). The Impact Of Financial Leverage On Firm Performance: The case of Non Financial Firms In Kenya, Research project submitted to the University of Nairobi, School of Economics in partial fulfillment for the award of the Degree of Masters of Arts in Economic Policy Management.

[3] Antão, P. \& Bonfim, D.( 2012). "The dynamics of capital structure decisions," Working Papers 201206, Banco de Portugal, Economics and Research Department.

[4] Bevan, A., \& Danbolt, J. (2000), Dynamics in the Determinants of Capital Structure in the UK, University of Glasgow, Working paper, 1-10.

[5] Cassia, L. \& Minola, T. (2011). Capital structure decision of new technology-based firms: evidence from youth entrepreneurship, Investment Management and Financial Innovations, 8 (4), 72-82.

[6] Ekwe, M., \& Inyiama, O. (2014). Revenue Reserves and Financial Performance in the Brewery Industry: Evidence from Nigeria. Applied Economics and Finance. Vol. 1, No. 2; 117-131.

[7] Ezeoha, A \& Botha, F. (2011). Firm Age, Collateral Value, and Access to Debt Financing in an Emerging Economy: Evidence from South Africa, Sajems Ns 15 (2012) No 1; 55 71. Granger, CWJ 1988, 'Some recent developments in a concept of causality', Journal of Econometrics. 39 (1/2), 161194.

[8] Granger, CWJ (1988). Some recent developments in a concept of causality. Journal of Econometrics.39(1/2), 161-194. Kraus, A \& Litzenberger, R 1973. A state-preference model of optimal financial leverage. Journal of Finance. 28 (4), 911922.

[9] Ghazouani, T. (2013). The Capital Structure through the Trade-Off Theory: Evidence from Tunisian Firm, International Journal of Economics and Financial Issues. 3 (3), 625-636.

[10] Harrison, B. \& Widjaja, T. (2013). Did the Financial Crisis Impact on the Capital Structure of Firms? Discussion Papers in Economics, Nottingham Trent University, $1-45$.

[11] Johansen, S., \& K. Juselius, (1990) 'Maximum Likelihood Estimation and Inference on Cointegration - With Applications to the demand for money', Oxford Bulletin of Economics and Statistics. 52,169-210. 
[12] Mueller, D, C. (1972). A Life Cycle Theory of the Firm, "Journal of Industrial Economics" 20 (3), 199-219.

[13] Maina, L \& Kondongo, O. (2013). Capital Structure and Financial performance in Kenya: Evidence from Firms Listed at the Nairobi Securities Exchange. Paper presented at the Jomo Kenyatta University of Science and Technology, SHRD Research Conference, Kenya, pp 238-246.

[14] Myers, S. C. (2001), Capital Structure. "Journal of Economics Perspectives." 15 (2), 81-102.

[15] Pasquale, F. (2006). "Testing for Granger Causality between Stock Prices and Economic Growth". MPRA Paper 2962, University Library of Munich, Germany, revised 2007.

[16] Rajan, R. \& Zingales, L. (1995), What Do We Know about Capital Structure - Some Evidence from International Data, Journal of Finance 50 (5), 1421-1460.
[17] Sherif, M. \& Elsayed, M. (2013). The Impact of Corporate Characteristics on Capital Structure: Evidence from the Egyptian Insurance Companies, Pacific-Basin Finance Journal, $1-27$.

[18] Robb A. \& Robinson, D. T. (2009), The capital structure decision of new firms [Online] Available: http://papers.ssrn.com/so13/papers.cfm?abstract-id=1345895 [Accessed: 17 October 2009].

[19] Titman, S. \& Wessels, R. (1988), The Determinants of Capital Structure Choice. Journal of Finance. 43, 1-19.

[20] Tamimi and Takhtaei (2014). Relationship between Firm Age and Financial Leverage with Dividend Policy. Asian Journal of Finance \& Accounting. 6, (2). 